\title{
Why some Muslims Engaged in Violence: A militarised Mentality
}

\author{
Ilyas Mohammed ${ }^{1 *}$ \\ ${ }^{1}$ Department of Sociology, Social Policy and Criminology, School of Law and Social Justice, \\ University of Liverpool, Foundation Building, Brownlow Hill, Liverpool, L69 7ZX, United \\ Kingdom.
}

Received: 2020-12-25; Accepted: 2021-03-07; Published: 2021-04-30

\begin{abstract}
Since 9/11 countering different types of violence through CVE and PVE programs have become a central policy concern for many in the Western and non-Western countries such as the UK, France, the United States and Indonesia. These countries have launched various CVE and PVE programs to prevent what scholars call radicalisation and de-radicalise those dammed to have been radicalised. These programs' focus is often to build community resilience and persuade individuals to adopt a liberal or state-oriented understanding of Islam. However, how successful these programs are is not clear. In some cases, these programs have been counterproductive because they have fostered Islamophobia and mistrust, as is the case with the UK's Prevent strategy. This paper will take the UK as a case study and propose a non-religious conceptual framework by using strain and fusion theory and interview data to explain why some British Muslims decided to engage in terrorism. In doing so, the paper will argue that if the UK government is to prevent such decisions, it needs to focus on addressing the socio-political causes that engender motivations to engage in terrorism.
\end{abstract}

Keywords: British; Prevent; Islam; Radicalisation; Terrorism; Violence; ISIS, Criminology; Anthropology

How to Cite: Mohammed, I., (2021). Why some Muslims Engaged in Violence: A militarised Mentality. Journal of Contemporary Governance and Public Policy, 2(1), 13-30. https://doi.org/10.46507/jcgpp.v2i1.31.

Permalink/D0I: https://doi.org/10.46507/jcgpp.v2i1.31 


\section{Introduction}

Over the last few decades, countering terrorism has become a central policy concern for Western and non-Western countries. Governments have rolled various CVE and PVE programs to prevent radicalisation and terrorism based on anticipatory logics, including spying, entrapment, surveillance (offline and online), community resilience building, community cohesion and disseminating a moderate or statecentric interpretation of Islam (Martin, 2014). Western and nonWestern governments have invested large amounts of resources to counter the threat of terrorism. In its 2018/19 budget, the British government announced that it would spend $£ 757$ million on counterterrorism policing, increasing $£ 50$ million from the previous year (Home Office, 2018). The increase in funding attests to the seriousness of the radicalisation and terrorism problem in the UK. That said, the Prevent strategy, which is the government's flagship strategy, has revied a lot of criticism from MPs (Member of Parliament), senior police officers, human rights organisations and the Muslim community. The criticisms include making British Muslims into a suspect community, creating a hierarchy among Muslims, creating mistrust between communities, fostering Islamophobia, and the radicalisation model is based on flawed research.

In this paper, I will first critique how the Prevent strategy and the science behind the radicalisation model employed by the UK government. The paper is based on interview data and several highprofile cases of individuals who intended or engaged in terrorist violence. I will then elaborate on a tentative conceptual framework by employing strain and fusion theory to explain why some British Muslims living outside conflict zones decided to use terrorist violence. The framework professes that the chances of an individual residing outside a conflict zone to use terrorist violence to defend a group they identify with and relate to will increase if the following criteria are met. (1) If he or she has experienced vicarious strain because of a group that he or she identifies with and relates to is experiencing strain because of violence inflicted on it; (2) He or she has become intensely fused with the strained group; (3) $\mathrm{He}$ or she has thoroughly internalised the suffering of the strained group; (4) He or she has developed a militarised mentality. The paper is based on interview data and several high-profile cases of individuals who intended or engaged in terrorist violence.

\section{Research Methods}

In this section, I will discuss the methodological approach taken. The paper is based on primary and secondary research. I adopted a qualitative methodology because it enables the researcher to show how individuals make sense of their experiences through their interpretive frameworks. As Hakim (2000, p. 34) notes, it "illuminates the motivations that connect attitudes and behaviours, the discontinuities, or even contradictions, between attitudes and behaviours, or how conflicting attitudes and motivations are resolved, and particular choices made".

\section{Sampling frame}

I used snowballing to gain access to Muslim Against Crusades (MAC) members and the one foreign fighter that I interviewed. Extremist groups like MAC and individuals that have engaged in violence are hard-toreach because of two main reasons. One, because members do not trust researchers and deem them as 
government spies and secondly, because of anti-terrorism legislation (Gilbert, 2001). The research for this paper involved conducting interviews with members of MAC and one former foreign fighter. In total, six interviews were conducted. Other MAC members and former foreign fighters were approached, but they did not want to be interviewed. I also tried to seek permission from the British government to interview people convicted of terrorism offences, but the request was turned down. The following examples illustrate the mistrust of researchers. For example, some interviewees cancelled on the day of the interview, citing that they could not trust me. Others asked if I was working for the British government. These comments are not surprising because MAC and other similar groups operating in the UK, such as Hizb ut Tahrir do not trust the British government. Moreover, sections of the British Muslim community also share the mistrust of the British government, especially on its counterterrorism strategy known as Prevent, which involves community cohesion initiatives, and in some cases spying on the community through informants and spy cameras' (Shanaah \& Lindekilde, 2019).

Two considerations informed the interviewees' recruitment for this paper: legislative risks to the researcher and the researchers' mistrust. Rizwan Sabir's case exemplifies the legislative risks researchers are exposed to when researching terrorism (Townsend, 2012). The police accused Rizwan of downloading an al-Qaida training manual for terrorist purposes. However, Rizwan had downloaded the manual from the US government website for his research while undertaking an MA at Nottingham University in 2008. With the British government's plan to tighten antiterrorism legislation, critics have dubbed as 'criminalising curiosity'. The legislation threatens the freedom of academics to research terrorism (Grierson, 2018). The legislation would mean that terrorism research would be fenced off for governmentapproved researchers and think tanks. The fencing off would likely result in uncritical, state-centred racialised research. Such legislation is likely to foster more mistrust between British Muslims, the British government and the wider British society and increase Islamophobia in Britain.

However, I was able to overcome the mistrust and legislative risks connected to researching sensitive topics:

By drawing on the interpersonal resources and strategies that we all tend to develop in dealing with everyday life. Not only does its achievement depend upon theoretical understanding, often disguised as 'native wit (Hammersley and Atkinson 1996: 54).

I was able to gain access to members of MAC and former foreign fighters because of my informal network of contacts, knowledge about Al-Muhajiroun and being aware of the political concerns of the British Muslim community. However, as (Hammersley \& Atkinson, 1996) notes:

The discovery of obstacles to access and perhaps effective means of overcoming them provides insights into the social organisations of the setting.

The obstacles that I encountered made me reflect on the precarious nature of researching sensitive issues and the constant need and pressure on researchers to maintain rapport and trust with hardto-reach extremist groups because a researcher is always one step away 
from being labelled a spy. However, the interview can also be a transformative and healing experience for the interviewee and researcher, especially if issues discussed are sensitive and traumatic. The interview with the former foreign fighter allowed him to speak about racism, his emotions when he saw pictures of Bosnian Muslims in camps, and his motivations that led him to Bosnia's battlefields in the 1990s. The interviews made me realise the immense impact that strain on an identifiable and relatable group can have on an individual.

\section{Data collection}

The primary data was collected using semi-structured interviews because the advantage of the interview method is that it allows "the identification of patterns of associations between factors on the ground. Interviews can also clarify the reasons for the discrepancy between stated attitudes and behaviour" (Hakim, 2000). I conducted five interviews with MAC members, a reincarnation of the banned group Al Muhajiroun and one with a former foreign fighter who took part in the Bosnian war in the 1990s. The interviews were conducted in spaces that the interviewees and researcher agreed would be the safest. The interviews with MAC members were conducted in cafes in East London, which is predominantly a Muslim area. The interview with the former foreign fighter was conducted in his home. During the interviews, a variety of issues were discussed, but in this paper, I will only refer to material relevant to this paper's subject. Alongside the interviews, I also used secondary data such as videos, magazines, websites, and books authored by extremist groups to supplement the interview data.
Accessing secondary data also involves a certain amount of risk due to the type of material uploaded by extremist groups' to Twitter and other internet platforms. There are laws prohibiting individuals from gaining access to or owning material produced by banned groups (BBC, 2012).

\section{Ethics}

The research conducted for this paper did not involve covert research, and consent was gained from the interviewees by asking them to complete a consent form before the interview. The form detailed the research's purpose, the academics involved, the funder's name, and how the research will be disseminated. Goldsmiths University gave ethical approval for the research.

\section{Results and Discussion}

\section{Critical reflections on the Prevent strategy}

This section of the paper will critically discuss the UK government's Prevent strategy because it informs how the government and frontline service providers understand radicalisation and prevention. Over the last few years UK's counterterrorism policy, especially its Prevent strand, has come under massive criticism from human rights groups, academics, politicians and Muslim advocacy organisations. Despite this, the government so far has resisted the pressure calling on it to abolish Prevent. Among those who have called for Prevent to be abolished is Labour MP Andy Burnham. He called for Prevent to be scrapped, considering it to be a toxic brand (Perraudin, 2016). Former senior police officer Dal Babu also called the brand toxic and said that the Muslim community has no trust in it (Halliday \& Dodd, 2015). In September 2016, 140 academics 
signed a petition calling for an open debate about the 'science' behind Prevent (Ross, 2016). UK based human rights organisation 'Human Rights Watch UK', in its 2016 report, said that Prevent "is not fit for purpose, and its effect on education and student's human rights raises serious concerns" (Human Rights Watch, 2016). Similar conclusions were reached in the report by Open Society, stating that "the UK's Prevent strategy, which purports to prevent terrorism, creates a serious risk of human rights violations. The program is flawed in both its design and application, rendering it not only unjust but also counterproductive" (Open society Foundation, 2016). Whilst space does not permit a complete discussion of Prevent's failures. Two issues will be discussed. Firstly, the Prevent strategy science provides the risk indicators used as anticipatory and precautionary interventions as part of community cohesion and resilience-building initiatives. Two, the mistrust created between Muslims, the government and the wider British society by Prevent.

The science behind the Prevent strategy has two major problems. On the one hand, it is not available for academic scrutiny and on the other, it does not consider UK foreign policy/political context as being an important indicator for radicalisation. As such overemphasises ideology over nonideological factors. The government's rationale for not making the science accessible is for national security reasons (Qureshi, 2016). Nevertheless, the UK based advocacy group Cage has published a report that details a review of an article written by Monica Lloyd and Christopher Dean titled 'The Development of Structured Guidelines for Assessing Risk in
Extremist Offenders', which was published in 2015. The article is significant because it discusses the research carried out to develop the ERG22+ framework while at the National Offender Management Service's (NOMS). The research is relevant because it is used by the Prevent strategy to identify vulnerable and radicalised individuals and de-radicalise them through the Channel program (Qureshi, 2016).

The Cage report is crucial because it, for the first time, makes the science underpinning Prevent accessible to academics, media and the British public. The NOMS framework provides 22 indicators, which are used to determine the vulnerability of an individual to radicalisation. Questions can be asked about why some of the indicators, such as 'transitional periods', make Muslims more vulnerable to radicalisation than members of other faith and no- faith communities (Qureshi, 2016). However, the more relevant question is to inquire about the security practices that the framework has justified, such as the widening of the surveillance net based on the indicators Morris (2004 cited in Mythen (Mythen, Walklate, \& Khan, 2009) shows that in the post 9/11 British "Asian people stopped and searched under anti-terrorism laws in the UK rose by near on $400 \%$, from 744 in 2001-02 to 2989 in 200203". This trend has not slowed down, and the 2015 statistics from the Home Office reveal a remarkable increase in the arrest of Asian appearing individuals: "The year ending 31 March 2015, the number of terrorism-related arrests increased across all ethnic groups. Most notably, those arrested who were of Asian ethnic appearance increased by $36 \%$ taking the number of arrests of that ethnic group to its highest since 
data collection began on 11 September 2001. Those of Asian ethnic appearance accounted for 140 (or $47 \%$ of) arrests in the year ending 31 March 2015" (Home Office Statistics, 2015). This situation has not only made British Muslims, as (Kundnani, 2012) argues, a suspect community, but it also constructs them as at ever-potential danger of being radicalised and, as Martin (Martin, 2014) notes, a constant threat to the UK. The result of this has been the silencing and alienation of Muslims (Hickman, Thomas, Nickels, \& Silvestri, 2012) because they fear expressing their views about issues, such as the Palestinian and Israeli (Hooper, 2017), and the Syrian conflicts place them at risk of being deemed as radicalised. Although conflicts involving Muslim suffering (Ilyas, 2013) and foreign policy are essential factors contributing to radicalisation, neither the ERG22+ framework nor Prevent consider them as indicators for radicalisation despite Lloyd and Dean (2015) indicating in their article that:

None of the British AQinfluenced offenders we spoke to wanted to establish an Islamic government in the United Kingdom. Their goals were to alleviate Muslims' suffering elsewhere and express their antagonism to British and American foreign policy in Muslim countries.

This situation indicates that the political context, especially foreign policy, was essential in the UK context to explain Muslims' radicalisation and should have been considered. Even more troubling is that Monica Lloyd and Christopher Dean were advised to consider the political context because it was deemed a distinct feature of Islamist extremists, but they failed to do so (Lloyd \& Dean, 2015). The omission of the political context is highly problematic because academics, advocacy groups, and a large section of the British Muslim community have long argued that foreign policy plays a significant role in radicalising Muslims (Kundnani, 2012; Lloyd \& Dean, 2015; Qureshi, 2016). Even the former head of MI5, Dame Eliza Manningham during the Chilcot inquiry said that the Iraq invasion has "substantially increased the threat of terrorist attacks in Britain and was a significant factor behind the radicalisation of young Muslims in the UK" (Norton-Taylor, 2010). Talking to the Guardian newspaper, Monica Lloyd said: "the original study was not an academic piece of work... The methodology could not be developed through a conventional academic approach. Some offenders would not speak to them, while others changed their minds about cooperating 'at the last minute" (Ross, 2016). Academics that commented on the research, such as Professor David Miller, have said that: "this is secret research, and we can't interrogate what the process was that leato the material in the original report. It's not academic research, it's not social science - it's an internal report and not in any way a sound basis for making any kind of policy" (Ross, 2016). The Royal College of Psychiatrists has called for the:

Data on evaluations of Prevent, as with any initiative requiring public services to alter their practice, must be in the public domain and subjected to peer review and scientific scrutiny. Public policy cannot be based on either no evidence or a lack of transparency about evidence. The evidence underpinning the UK's Extremism Risk Guidance 22+ (ERG22+; HM Government 2011c), and other 
data relating to this guidance, should be comprehensively published and readily accessible" (Goniewicz, Khorram-Manesh, Hertelendy, \& ..., 2020).

This research not only raises grave concerns about the lack of scrutiny but also about the government's willingness to use scientifically untested and small-scale research to elaborate national programs. This situation occurred despite Lloyd and Dean stating that the "ERG is a work in progress" (Lloyd \& Dean, 2015). Advocacy group Cage has said the government is using the Muslim community "as lab rats" (Abbas, 2016) to test the research. This situation, coupled with the absence of discussion on the UK's foreign policy and the labelling and stigmatising of UK Muslims as a suspect community, has produced a climate of mistrust of the government among some Muslims (Donaghy, 2015).

\section{Strain theory and the turn to violence}

In the previous section I have mention several problems connected to the Prevent strategy. If the UK government takes the advice of Labour MP Andy Burnham, then all it needs to do is to scrap prevent because it is toxic. However, this will not address the the problems connected to the science behind the radicalisation model the Prevent strategy employs. To address this problem an alternative conceptual framework needs developed, which will better explain why some British Muslims either intended or engaged in terrorist violence. This section will flesh out the theoretical influences that underpin the conceptual framework and detail the framework. The framework is based on strain and fusion theory because both offer important insights into why an individual who has not directly experienced strain emanating from violence decides to use violence to defend or further the cause of those experiencing the strain directly.

According to Agnew (2002, 2010), there are many types of strain, including objective, subjective, collective and vicarious. For this article, collective and vicarious strain and the accompanying idea of linkedfate are relevant. Agnew (Agnew, 2010) notes that:

Terrorism is most likely to result from the experience of 'collective strains' or strains experienced by the members of an identifiable group or collectivity, most often a race/ethnic, religious, class, political, and/or territorial group. These strains are: (a) high in magnitude, with civilian victims; (b) unjust; and (c) caused by significantly more powerful others, including complicit civilians, with whom members of the strained collectivity have weak ties.

In the above quote, Agnew identifies three causes that result from collective strain, which could lead to violence. These are: (1) severe strain where the victims are innocent civilians, (2) the strain is unjust and (3) strain is caused by a powerful other. In the same article, he also stresses that only a small percentage of those who endure collective strain engage in violence. Sageman (2008) and Borum (2011) also provide similar explanations to explain why some people engage in violence. Sageman argues that the moraloutrage engendered by real or perceived injustices and accompanying discourses that necessitate the need for action lend 
themselves to an individual or a group using violence. Borum (Borum, 2011) concludes that feelings of injustice and identarian politics act as motivations for individuals or groups to use violence. The central theme that emerges from the three explanations is the experience of strain emanating from 'unjust treatment' of an identifiable and relatable group, which produces a range of negative emotions and responses, including violence. Coreligionists being unjustly treated by a more powerful 'other' was a common theme expressed by members of MAC, such as Palestinians being subject to Israeli violence and the 2004 illegal invasion of Iraq by the US and its allies (Interview 1, 2, 3, 4 with MAC member, 2011).

Connected to collective strain is the vicarious strain experienced by individuals who do not directly experience the strain. However, they are nevertheless impacted by it because the strain victims are identifiable and relatable to several identity registers. Agnew defines vicarious strain as:

Vicarious strain refers to the real-life strain experienced by others around the individual, especially close others like family members, friends, and (possibly) community residents. The individual may directly witness the strain experienced by these others (e.g., such as an assault), may hear these others experience strain (e.g., gunshots, screams), or may hear about the strain of these others (e.g., from victims or in the media. (Agnew, 2002).

It is essential to factor in vicarious strain because it is experienced by those who are not direct victims of the strain but connected to the victims through various identity registers, such as political, ethnic and even religion. Individuals who experience vicarious strain can live either inside or outside conflict zones. As such, it is essential to include vicarious strain when trying to explain why an individual living in Britain would decide to use violence on behalf of a group that he or she identifies with and relates to and is experiencing strain in a conflict zone.

Connected to both collective and vicarious strain is the idea of linked-fate. Linked-fate is a 'relationship' that connects individuals that share identity registers, such as family, ethnicity, religion, nationalism and politics. This relationship is activated when an individual or group that is not directly experiencing strain becomes aware of the strain experienced by other individuals or a group that they can identify with and relate to through identity registers. Agnew (Agnew, 2010) defines linked-fate as:

Linked fate', or an 'acute sense of awareness (or recognition) that what happens to the group will also affect the individual member'... And it creates a sense of obligation to protect others in the collectivity, at least among those traditionally cast in the protector role. This collective orientation helps explain the terrorism of those who have not personally experienced severe strain. Such individuals strongly identify with others in the collectivity and, through this identification, they vicariously experience, feel personally threatened by, and feel responsible for alleviating the strain experienced by these others.

Like the vicarious train, linked-fate is vital to consider when 
speaking about the use of violence among those who do not directly experience the strain because for three reasons. Firstly, linked-fate acts as an emotional glue that connects individuals, secondly, it indicate a robust relationship, and finally, it engenders 'obligations and responsibilities to act' and defend or further the cause of an identifiable and relatable group. The acting on the obligations and responsibilities could include violence. The idea of linkedfate played a prominent part in MAC members' identity because they regarded all Muslims as part of the ummah, the global Muslim family (Interview 5 with MAC member, 2011).

However, it is unlikely that an individual would be compelled to use violence if they were not intensely fused and had not thoroughly internalised a strained group's suffering, which is discussed in the next section.

\section{Fusion theory and the turn to violence}

In this section, I will discuss how fusion theory can help to understand why an individual may decide to use violence to defend or further the cause of a strained group that is identifiable and relatable to him or her. Like strain theory, fusion theory is an important theory for this paper because it asks questions such as, "why do some soldiers instinctively risk life and limb for their compatriots?" (Swann Jr \& Buhrmester, 2015). Answering this question is essential to understand why an individual decides to use violence to defend or further the cause of a strained group that is identifiable and relatable. Swann et al. (2012) define identity fusion as:

Identity fusion occurs when people experience a visceral feeling of oneness with a group. The union with the group is so strong among highly fused persons that the boundaries that ordinarily demarcate the personal and social self-become highly permeable.

The theory is intellectually influenced by the work of 14thcentury Muslim sociologist Ibn Khaldun and his concept of Assabiyah and by the 19th-century sociologist Emile Durkheim and his idea of mechanical solidarity. In basic terms, both concepts refer to how identity registers bind individuals together into a group, such as a kinship, tribe and nation (Whitehouse et al., 2014). However, fusion does describe not only togetherness but also explains the visceral feelings of oneness. These feelings of oneness mean that an individual sees the group that he or she identifies with as an essential part of their identity. The identification means that the individual views themselves through the group's identity and has become fused with the group and developed 'relational ties' with other members. However, being fused means that the individual is more likely to engage in behaviour beneficial to the group and likely to encourage other members to do the same. According to Swann et al. (Swann Jr et al., 2012), "encouragement may be the enactment of unusually bold and potentially dangerous actions on behalf of the group". However, acting in bold ways, such as using violence, will only occur if the individual has become intensely fused with the group experiencing strain.

Swann et al. (2010), in their article titled, 'Dying and Killing for one's group', argue that fused individuals are willing to make the ultimate sacrifice to save members of their in-group. They further add that the decision to do so is one of moral 
agency that compels them to act to protect the in-group. Similarly, Whitehouse et al. (Whitehouse et al., 2014), in their article titled, Brothers in Arms: Libyan Revolutionaries bond like a family, conclude that fusion occurs because individuals feel that their experiences, especially those that define the self, are shared by others, which leads to fusion with the other members of the group.

However, being fused means that the individual has internalised the strained group's suffering that they identify with and relate to. The internalisation of suffering is based on two things. One, the feeling that the experiences that define the self are shared by the strained group. Two, linked-fate and accompanying obligations and responsibilities to act. The internalisation of suffering also narrows the emotional distance and simultaneously distinguishes those in the in-group from those in the outgroup. This situation is achieved by using what I term as 'familial emotions'. These emotions form the basis of how members of a biological family relate to each other. Individuals appropriate the vocabulary that expresses familial emotions that make the suffering of the strained group feel personal. The examples of individuals I provide in this paper employ Islamic vocabulary, such as brother, sister and ummah, to demonstrate their family-like relationship with members of the strained group that they identify with and relate to Ilyas (Ilyas, 2013). The internalisation of suffering is sustained and intensified because the group's strain continues, and the production of discourses connected to the strain are continuously circulated on many offline and online platforms. Such repetition results in the individual or some cases, the group constantly feeling, thinking and talking about wanting to take revenge. Such feelings and talk over time become normalised, but the thought of successfully attacking the enemy becomes a pleasurable experience. Such feelings are evident in the case of Hussain, whom I discuss later in this paper. Consequently, the strained group's continued suffering and circulation of discourses connected to the strained group deepens the commitment to the cause and hatred towards the other to such a level that violence becomes the only option.

The continuation of the strain and circulation of discourses connected to the strain results in two things. Firstly, the intimate experience of love, pain, humiliation, and suffering of a strained group is identifiable and relatable. Secondly, hate for the other that has brought on the suffering in such a way that it engenders a desire to gain revenge and end the suffering, which is evident in the cases I discuss in this paper.

Before an individual can respond to the strain experienced by a group they identify with and relate to, they need to have developed what I have termed as a duty mentality, which I detail in the next section. This mentality can take the form of humanitarianism or militarism. In some cases, an individual can move from a humanitarian to a military mentality or vice versa, as exemplified by a foreigner fighter who fought in Bosnia during the 1990s that I discuss later in the paper. Why an individual or group develop either mentality is dependent on many factors. These include the intensity of fusion, the level of emotional and political attachment to the cause of the strained group, strategy and opportunity. 


\section{Duty mentality}

In this section, I detail what I have termed as the 'duty mentality', by which I mean a mindset and feelings that engender a duty to act and help a strained group that is identifiable and relatable to him or her. The acting could entail developing either a humanitarian or military mentality. The former could entail doing humanitarian work, joining a political organisation, or writing about the strained community. The latter entails using violence, which could be political or terrorist violence, depending on how violence is defined. However, this begs an important question regarding why some people adopt a military mentality and others a humanitarian one. Some individuals may not engage in violence because they believe that violence will not end the strained community's strain. Others may not see the perpetrators of violence as an enemy in a military sense, and they have not experienced a situation that could make them decide to engage in violence, such as described by Pape (2006) and Khosrakhavar (2005). Having said this, it is vital to detail why some individuals adopt a humanitarian mentality instead of a militarised one, which I do in a forthcoming paper. The humanitarian and militarised mentalities are the product of linked-fate, which engenders obligations and responsibilities on those who are impacted by the strain experienced by the strained group to act.

The following extract from an interview with a former MAC member demonstrates how linked-fate engenders obligations and responsibilities for an individual to act and alleviate the strained group's strain. He states:

Muslims are one, and it does not matter where they are from, nationalism, the country and their flag, none of this matter. You realise that these are like your brothers; these people are like your sisters, so we must have some allegiance with them, support them. So obviously with the knowledge of Islam creates the change in the person, so that the more he finds out, 'look those are really my brothers that are being oppressed in Palestine, I need to support them'. The Prophet's hadith says the ummah is like a body if one body hurts if one part hurts the rest of the body feels it. (Interview 2 with MAC member, 2011).

From the interview extract, it seems that the Palestinians' strain is vicariously experienced by the interviewee, which activated linkedfate and the accompanying responsibilities to act and alleviate the strain experienced by the Palestinians. However, from the extract, it is not clear what the interviewee means by 'supporting'. Supporting could entail humanitarian work or the use of violence. As such, it is not clear what mentality the interviewee has developed. However, other former MAC members such as Al-Britani and Abu Rumaysah had developed a militarised mentality and joined ISIS in Syria (Doyle, 2014) and engaged in homegrown terrorism, such as Khuram Shahzad Butt (Booth, Cobain, Dodd, Taylor, \& O'Carroll, 2017).

\section{The militarised mentality}

This section will show how one develops a militarised mentality. An individual develops a militarised mentality when he or she thinks and feels that all non-violent avenues have been exhausted or violence is deemed the only option to end the suffering experienced by the strained 
group that is an identifiable and relatable individual. The mentality creates a mindset through which the individual sees the group that has brought on the strain as the enemy in a militarised sense. As such justifying violence. The mentality is similar to that of a soldier after military training:

To shape attitudes towards killing and to train individuals in the behaviour necessary to kill. The processes used to shape attitudes towards killing include de-pluralisation, otherde-individuation, and dehumanisation; the process of dehumanisation to discharging weapons is used to shape behaviour (Britt, Adler, \& Castro, 2006, p. 21).

By dehumanising, the individual suspends the norms that ordinarily prevent violence, which means that the emotions and discourses connected to the group experiencing strain are experienced in a militarised way. The mentality engenders a desire and necessity to use violence to defend an identifiable and relatable strained group. In doing so, the mentality simultaneously works to intensify in-group unity, loyalty and obedience. This situation, in turn, not only intensifies the emotional attachment to the strained group but also justifies the use of violence, as well as simultaneously circumventing guilt connected to the use of violence.

The internalisation of the suffering automatically invokes and simultaneously multiplies the importance of discourses that detail the strained group's suffering at the hands of a more powerful other. The discourses are embedded with loyalty, love, hate, vulnerability, survival, fear, loss, brother, sister, and pain and are based on past and present strains. The discourses solidify in-group and out-group distinctions and legitimise the use of violence against the latter on the grounds that it is ethically and morally justified and acceptable because it is in defence of an identifiable and relatable strained group.

\section{The militarised mentality in practice}

In this final section of the paper, I will discuss how the militarised mentality unfolds. I do so by using the cases of Mohammad Sidique Khan, who was one of the $7 / 7$, a foreign fighter who fought in Bosnia in the 1990s, Roshanara Choudhry, who attacked a British MP, Tanvir Hussain \& Abdullah, who planned to blow up a transatlantic flight in 2006 and two Syrian foreign fighters.

Starting with Khan, in his martyrdom video, he states that:

Your democratically elected governments continuously perpetuate atrocities against my people and your support of them makes you directly responsible, just as I am directly responsible for protecting and avenging my Muslim brothers and sisters. Until we feel security, you will be our target. Until you stop the bombing, gassing, imprisonment and torture of my people, we will not stop this fight. We are at war, and I am a soldier. Now you too will taste the reality of this situation (The Sunday Times, 2005).

Khan's comments illustrate that he has developed a militarised mentality. From his comments, it is clear that he has experienced vicarious strain because he lived in the UK. As a consequence of the vicarious strain, Khan has become 
intensely fused with his coreligionists experiencing strain in conflict zones because he has internalised their suffering through the registers of Islam and politics. He has internalised the suffering to such an extent that he feels oneness with his coreligionists and makes the ultimate sacrifice (Swann Jr et al., 2010) to defend his coreligionists. The extent of the internalisation of suffering was also due to linked-fate, which he indicates by making the following comment, "until we feel security, you will be our target. Until you stop the bombing, gassing, imprisonment and torture of my people, we will not stop this fight" (The Sunday Times, 2005). Khan translates and acts on the obligations and responsibilities engendered by linked-fate by becoming a soldier and a human bomber.

In a different context, a former foreign fighter who fought in the Bosnian war in the 1990s explained to me in an interview why he decided to fight and defend his coreligionists in Bosnian. He said:

We were handing out food to Bosnian Muslims, but we ran out, but many people were waiting to be given food. We could hear them from where we were handing out food. To get to the exit of the building from where we were, we had to walk past all the men, women, and children waiting to receive food from us. It would generally take us forty seconds to walk from the hall where we were handing out food to the exit, but it felt like it took hours on this occasion. As we walked past the men, women and children, the women were crying and pointing towards mouths, and they were showing us skinny babies who had not eaten for days. The children were tugging at our clothes and pointing to their mouths. I felt horrible, and I felt sick. I had tears in my eyes. My body felt heavy. By the time we had reached the building's exit, I had decided that I wanted to stay and do more because what I had done was not sufficient. My colleagues tried to convince me to travel back to the UK with them, they told me we have done what we came out to do, it's time to go back home, but I had decided, and nothing was going to change my mind. Something inside me told me it was my duty to stay and do more than I had done. Feeding them was not enough. I had to defend them, they were my fellow Muslim brothers and sisters, and they had no one. After about 20 minutes, a car pulled up, and the man inside asked me what I was doing here. I explained to him what had happened and what I wanted to do. He took me with him, and I joined his group (Bosnia foreign fighter, interview, 2012).

Like Khan, the foreign fighter has also developed a militarised mentality. His comments clearly illustrate that he has experienced vicarious strain by witnessing the suffering of his coreligionists. Consequently, the fighter has become intensely fused and has thoroughly internalised his coreligionists' suffering through the register of Islam and politics, leading him to feel oneness with his coreligionists. This internalisation of suffering also resulted in him acting on the obligations and responsibilities engendered by linked-fate, which is clear from the following comments: 
Something inside me told me it was my duty to stay and do more than I had done. Feeding them was not enough. I had to defend them, they were my fellow Muslim brothers and sisters, and they had no one (Bosnia foreign fighter, interview, 2012).

The fighter translates and acts on the obligations and responsibilities engendered by deciding to stay on in Bosnia and defend his coreligionists and be prepared to make the ultimate sacrifice.

Roshanara Choudhry attacked Labour MP Stephen Timms because he supported Iraq's invasion in 2004 (Dodd, 2010). Like Khan and the former foreign fighter, she also experienced vicarious strain due to continually listening to Anwar alAwlaki's lectures and watching videos that detailed the suffering of her coreligionists. In her interview with the police, she states that "I feel like it's worth it because millions of Iraqis are suffering, and I should do what I can to help them and not just be inactive and do nothing while they suffer" (Dodd, 2010). Due to experiencing vicarious strain, Choudhry has become fused with her coreligionists. Like Khan and the former foreign fighter, Choudhry has internalised her coreligionists' suffering through the registers of Islam and politics. In her police interview, she states:

As Muslims, we're all brothers and sisters, and we should all look out for each other, and we shouldn't sit back and do nothing while others suffer. We shouldn't allow the people who oppress us to get away with it and to think that they can do whatever they want to us, and we're just gonna lie down and take it (Dodd, 2010).
The internalisation of her coreligionists' suffering was to such an extent that it resulted in Choudhry internalising and translating the obligations and responsibilities connected to linked-fate to mean using violence. Like Khan, the former foreign fighter and Choudhry, Abdullah in his martyrdom video states:

Punish and humiliate the Kufar, to teach them a lesson that they will never forget, to tell them that we the Muslims are a people of honour, we a people of izza, we are brave, we are not cowards, and enough is enough, we have warned you many times to get out of our lands, leave us alone, but you have persisted in trying to humiliate us, kill us, and destroy us, Sheikh Osama warned you many times to leave our lands, now the time has come for you to be destroyed, you have nothing to expect but floods of martyrdom operations, volcanoes of anger and revenge erupting amongst your capitals, so taste that, what you have made us taste for a long time (Israel, 2010).

Like Chaudhry and Hussain, Abdullah has also developed a militarised mentality. In his martyrdom, it is clear that he has experienced vicarious strain, which is evidenced when he states, "leave us alone, but you have persisted in trying to humiliate us, kill us, and destroy us. So taste that, what you have made us taste for a long time" (Israel, 2010). He has become intensely fused with his coreligionists and has also thoroughly internalised his coreligionists' suffering that is experiencing strain in conflict zones through the registers of Islam and 
politics. Abdullah has Internalised the suffering of his coreligionists to such an extent that it resulted in him understanding the obligations and responsibilities connected to linkedfate to mean using violence to alleviate the strain experienced by his coreligionists by stating, "you have nothing to expect but floods of martyrdom operations, volcanoes of anger and revenge erupting amongst your capitals" (Israel, 2010).

Recent examples of individuals that have developed a militarised mentality are foreign fighters fighting in Syria. In an interview with Channel 4 News, one foreign fighter stated: "elderly women, the children were being killed by a brutal regime, I think that deeply affected me, it touched me, and I thought I could do something, to help, in one way or another, that's what pushed me to go"(Channel 4, 2015). Another foreign fighter, who also had fought in Syria told the same broadcaster that: "they say a picture says a thousand words, and when those pictures are moving pictures, and those are pictures of a mother holding a dead two-year-old, you don't need a preacher to tell you what is going on there is wrong" (Channel 4, 2015). In their comments, both fighters demonstrate that they have experienced vicarious strain when they speak about older women and children being killed and pictures saying thousands of words. Both fighters also demonstrate that they have become intensely fused and have thoroughly internalised their Sunni Muslim Syrian coreligionists' suffering. Like in previous examples, both former fighters have internalised their coreligionists' suffering in such a way that it has resulted in them understanding linked-fate and the connected obligations and responsibilities to mean using violence to alleviate the strain experienced by their coreligionists.

\section{Conclusion}

In this paper, I have argued that the UK Prevent strategy has many problems, such as making British Muslims into a suspect community, fostering mistrust and radicalisation model behind based on flawed science. To address the problems connected to the radicalisation model, I elaborated a conceptual framework to explain why some British Muslims living outside conflict zones intended or engaged in terrorist violence to defend their coreligionists who are experiencing strain and are identifiable and relatable. To develop the framework, I have used strain and fusion theory and examples of some British Muslims who used violence to defend their coreligionists who are experiencing strain. The framework consists of collective strain, vicarious strain and linked fate. Chronologically, the collective strain is followed by vicarious strain and then followed by linked fate and connected obligation and responsibilities to alleviate the strain experienced by an identifiable and relatable group. An individual is unlikely to use violence if he or she is not intensely fused and has not thoroughly internalised the strained group's suffering so that it is felt and understood as being personal suffering. It is at this point that the individual will develop what I have termed as the militarised mentality. The mentality creates a mindset where the group causing the strain is deemed the enemy in a militarised sense. The mindset also means dehumanising and suspending the norms that ordinarily prevent violence. Consequently, the mentality engenders a desire and necessity to use violence to defend a strained 
group that is identifiable and relatable to the individual.

\section{Acknowledgements}

We extend our sincere gratitude to the University of Liverpool for providing us with the financial support during research of this article.

\section{References}

Abbas, A. (2016). Prevent strategy using communities as "lab rats."

Agnew, R. (2002). Experienced, vicarious, and anticipated strain: An exploratory study on physical victimization and delinquency. Justice Quarterly, 19(4), 603-632.

Agnew, R. (2010). A general strain theory of terrorism. Theoretical Criminology, 14(2), 131-153.

BBC. (2012). Rizwan Sabir arrest notes 'made up".'

Booth, R., Cobain, I., Dodd, V., Taylor, M., \& O'Carroll, L. (2017). London Bridge attacker named as Khuram Butt.

Borum, R. (2011). Radicalization into violent extremism I: A review of social science theories. Journal of Strategic Security, 4(4), 7-36.

Britt, T. W., Adler, A. B., \& Castro, C. A. (2006). Military Life: The Psychology of Serving in Peace and Combat, Volume 1, Military Performance. West Port: ABCCLIO.

Channel 4. (2015). We were defending British values, say Syria Britons.

Dodd, V. (2010). Roshonara Choudhry: Police interview extracts.

Donaghy, R. (2015). UK government has "wrecked trust" with Muslim community, says rights group.
Doyle, N. (2014). British Isis fighter al-Britani threatens executions in Trafalgar Square.

Gilbert, N. (2001). Researching Social Life. London: Sage Publications.

Goniewicz, K., Khorram-Manesh, A., Hertelendy, A. J., \& ... (2020). Current response and management decisions of the European Union to the COVID19 outbreak: a review. Sustainability. Retrieved from https://www.mdpi.com/20711050/12/9/3838

Grierson, J. (2018). UK counter-terror bill risks criminalising curiosity - watchdog.

Hakim, C. (2000). Research Design, successful designs for social and economic research. London and New York: Routledge.

Halliday, J., \& Dodd, V. (2015). UK anti-radicalisation Prevent strategy a 'toxic brand.'

Hammersley, M., \& Atkinson, P. (1996). Ethnography: Principles in practice. New York: Tavistock.

Hickman, M. J., Thomas, L., Nickels, H. C., \& Silvestri, S. (2012). Social cohesion and the notion of 'suspect communities': a study of the experiences and impacts of being 'suspect'for Irish communities and Muslim communities in Britain. Critical Studies on Terrorism, 5(1), 89106.

Home Office. (2018). Police funding increases by $€ 450$ million in 2018.

Home Office Statistics. (2015). Police funding increases by $£ 450$ million in 2018.

Hooper, S. (2017). Revealed: Moazzam Begg used as case study of "extremism" in Prevent training. March 1, Middle East Eye. Available 
from: (accessed September 19, 2020).

Human Rights Watch. (2016). Preventing Education? Human Rights and UK counterterrorism Policy in Schools.

Ilyas, M. (2013). Islamist groups in the UK and recruitment. Contemporary Voices: St Andrews Journal of International Relations, 4(2).

Israel, S. (2010). Liquid bomb plot trio jailed for life.

Khosrakhavar, F. (2005). Suicide Bombers Allah's New Martyrs. London: Pluto Press.

Kundnani, A. (2012). Blind spot? Security narratives and farright violence. Security and Human Rights, 23(2), 129-146.

Lloyd, M., \& Dean, C. (2015). The development of structured guidelines for assessing risk in extremist offenders. Journal of Threat Assessment and Management, 2(1), 40.

Martin, T. (2014). Governing an unknowable future: The politics of Britain's Prevent policy. Critical Studies on Terrorism, 7(1), 62-78.

Mythen, G., Walklate, S., \& Khan, F. (2009). 'I'ma Muslim, but I'm not a Terrorist': Victimization, Risky Identities and the Performance of Safety. The British Journal of Criminology, 49(6), 736-754.

Norton-Taylor, R. (2010). Former MI5 chief delivers damning verdict on Iraq invasion.

Open society Foundation. (2016). Eroding Trust: The UK's Prevent Counter-Extremism Strategy in Health and Education.

Pape, A. P. (2006). Dying to Win, Why Suicide Terrorists Do It. London: Gibson Square Books.
Perraudin, F. (2016). Andy Burnham calls for "toxic" Prevent strategy to be scrapped.

Qureshi, A. (2016). The "science" of pre-crime: The secret "radicalisation" study underpinning PREVENT. London.

Ross, A. (2016). Academics criticise anti-radicalisation strategy in open letter.

Sageman, M. (2008). Leaderless Jihad. Pennsylvania: University of Pennsylvania Press.

Shanaah, S., \& Lindekilde, L. (2019). Standing up and Speaking Out? British Muslims' Collective Action against Islamist Extremism. Democracy and Security, 15(4), 386-407.

Swann Jr, W. B., \& Buhrmester, M. D. (2015). Identity fusion. Current Directions in Psychological Science, 24(1), 52-57.

Swann Jr, W. B., Gómez, Á., Dovidio, J. F., Hart, S., \& Jetten, J. (2010). Dying and killing for one's group: Identity fusion moderates responses to intergroup versions of the trolley problem. Psychological Science, 21(8), 1176-1183.

Swann Jr, W. B., Jetten, J., Gómez, Á., Whitehouse, H., \& Bastian, B. (2012). When group membership gets personal: A theory of identity fusion. Psychological Review, 119(3), 441.

The Sunday Times. (2005). London Bomber video: full statement: Transcript of Mohammad Sidique Khan's statement in a video released through AlJazeera.

Townsend, M. (2012). Police 'made up" evidence against Muslim student.'

Whitehouse, H., Lanman, J. A., Downey, G., Fredman, L. A., 
Swann Jr, W. B., Lende, D. H., ...

identification.

Current

Xygalatas, D. (2014). The ties

Anthropology, 55(6).

that bind us: Ritual, fusion, and

(C) 2021 by the Author. Submitted for possible open access publication under the terms and conditions of the Creative Commons Attribution (CC BY SA) license (https://creativecommons.org/licenses/by-sa/3.0/). 